\section{Investigation of Elementary Education Students' Attitudes towards the Use of Smart Boards}

\author{
Oğuz GÜRBÜZTÜRK
}

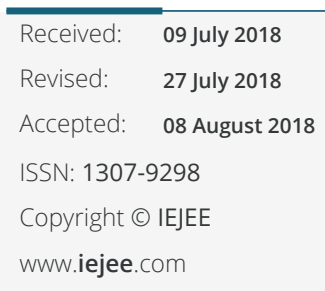

DOI: $10.26822 /$ iejee.2018143961

\begin{abstract}
The purpose of this research is to investigate the attitudes of elementary education students towards the use of Smart Board (SB) in lessons. The study is based on the associational survey model from quantitative research methods. The study was conducted on students attending at 4th to 8th grades of three schools, both primary and secondary stages, in Malatya province during 2016-2017 academic year. "Smart board attitude scale-SBAS" by Şad (2012) composed of 10 items and 5-point Likert scale was used in order to collect data. The result of the study revealed that elementary education students have a positive attitude on smart board usage in general. There was no significant difference in terms of gender while there was a significant difference in terms of the number of students in the classes, school type and grade.
\end{abstract}

Keywords: Smart board, elementary education, attitude, primary school, secondary school

\section{Introduction}

Countries form various systems to maintain their presence in accordance with the political regime they adopt. Educational systems undertake the mission of getting individuals to gain the knowledge and skills the era required them to have. That knowledge and skills are conveyed through programs at schools that emerged at the end of the process of education being institutionalized. The importance of the usage of various methods and techniques and materials during the implementation of the program is often stated in the educational surroundings. For the methods and techniques to be supported by appropriate materials, those materials should be sufficient in terms of quantity and qualification. During the education-training process, traditional materials used in the past are replaced by modern ones by the advanced technology. Those materials are increasing day by day in terms of number and function. Kenar (2012) states this truth that technological products which are the easiest way of accessing knowledge have begun to be used frequently at schools. Today, computers, projectors, smart boards (SBs), various hardware and software are the prominent examples of those products. Smart board is a tool which is used frequently in the classroom because it works multi-directionally.

Smart boards have begun to be used in education at the end of the 1990s (Beeland, 2002). Schools are equipped with smart boards as part of FATIH (Movement of Enhancing Opportunities and Improving Technology) project started in 2010, in Turkey. Although they are often referred to as interactive white boards, electronic white boards, or smart boards, their forms of usage is similar (Erduran \& Tataroglu, 2009; Türel \& Demirli, 2010). Smart board is appropriate for being computer-projector link as well as being touch-oper- ated. When the literature is examined, it is seen that smart boards are tools that support learning-teaching process (Adıgüzel, Gürbulak \& Sarıçayır, 2011; Çelik \& Atak, 2012; Geer \& Barnes, 2007; Kennewell \& Beauchamp, 2007).

According to the literature, the contribution of SBs to the learning-teaching process can be handled in two dimensions (Şad, 2012). First, the contribution to instructional excellence; second is the contribution to learning process. According to the findings obtained from various studies, SBs can make teaching more effective by being suitable for usage of three major senses i.e. seeing, hearing, and touching (Beeland, 2002; Hall \& Higgins, 2005; Gündoğdu, 2014); as its rich visual presentation tools, teachers' use of photos, flash animations, videos (Ates, 2010), voice records and sound effects (Hall \& Higgins, 2005) and also because of the interactivity of the screen, teachers and students' interference to the drawings, writings on the board (Erduran \& Tataroğlu, 2009). SBs contribute to the learning by increasing motivation (Smith, Higgins, Wall \& Miller, 2005; Türel \& Demirli, 2010); providing students' active participation (Beeland, 2002; Elaziz, 2008); taking attention (Levy, 2002; Morgan, 2008); and considering individual differences (Beeland, 2002; Gündoğdu, 2014). Besides these contributions, the use of SBs have also limitations. Some of these limitations are necessitating hardware and software for working with computer technology; not being used in every lesson; being expensive, and lack of information and skills of teachers related to the use of SBs (Higgins, Beauchamp \& Miller, 2007) and not being suitable to use with every teaching method.

SBs' contributions and limitations above can create various experiences and impressions in students. Students also obtain different affective behaviors by SBs in the teaching pro- 
cess besides they get knowledge and skills. One of these affective behaviors is attitude. Generally, attitude means the individual's view to a person or an object. According to Smith (1968), attitude means a tendency which attributes to the individual and forms his/her thought, emotion and behaviors related to a psychological object in a proper way (as cited in Kağıtçıbaşı, 2008, p. 110). According to this definition, attitude provides consistency in the individual's emotion, thought and behaviors towards an object.

Students' attitudes towards SBs as a technological product form the accumulation which they obtain from it. Each student's attitude towards SBs can be at different levels. This difference can stem from students' personal properties, exposure time, and exposure place and exposure conditions of SBs. That's why at every educational stage (elementary education, secondary education, higher education) or lessons in which they are used, students' level of attitudes towards SBs and the factors they are influenced by can be dealt with. However, this research emerged from the need to investigate the attitudes of elementary education students towards the use of SBs.

\section{Purpose}

The purpose of this research is to investigate elementary education students' attitudes towards the use of Smart Board in terms of several variables. In order to reach this purpose, answers of the following questions were looked for:

Table 1. Demographics related to participants

\begin{tabular}{|c|c|c|c|}
\hline Variable & & $n$ & $\%$ \\
\hline \multirow{3}{*}{ Gender } & Girl & 257 & 45.2 \\
\hline & Boy & 312 & 54.8 \\
\hline & Total & 569 & 100.0 \\
\hline \multirow{3}{*}{ Number of students in the class } & $16-25$ & 168 & 29.5 \\
\hline & $26-35$ & 401 & 70.5 \\
\hline & Total & 569 & 100.0 \\
\hline \multirow{4}{*}{ School type } & Higher SES & 168 & 29.5 \\
\hline & Middle SES & 219 & 38.5 \\
\hline & Lower SES & 182 & 32.0 \\
\hline & Total & 569 & 100.0 \\
\hline \multirow{6}{*}{ Grade } & 4 & 62 & 10.9 \\
\hline & 5 & 111 & 19.5 \\
\hline & 6 & 146 & 25.7 \\
\hline & 7 & 132 & 23.2 \\
\hline & 8 & 118 & 20.7 \\
\hline & Total & 569 & 100.0 \\
\hline
\end{tabular}

selected randomly from each grade of these three schools. Demographics about participants are presented in Table 1.

\section{Data collection tool}

To collect data, 5-point (Strongly agree, agree, slightly agree, disagree, strongly disagree) Likert type "Smart Board Attitude Scale" developed by Şad (2012) for 4th-8th grade students was used. The scale is composed of two factors. The factor loadings of items $(1,4,7,8$ and 9.) in the first factor that includes negative attitude statements about smart board usage are between .821 and .680 . The items' factor loadings $(2,3,5,6$ and 10.) in the second factor that includes positive attitude statements are between
1. How are the elementary education students' attitudes towards the use of smart board in general?

2. Is there a significant difference between their attitudes towards smart board usage in terms of their gender, the number of students in the class, school type, and grade?

\section{Method}

In this study, the associational survey model, which is one of the quantitative research methods, was used. Survey model is an approach that determine a situation in the past or existing now as the way it is. Furthermore, it includes data gathering to examine various features of a group. The event, person or object that is the topic of research is tried to be defined as the way it is and in its own circumstances. There is no effort to change or affect it in any way (Büyüköztürk, Çakmak, Akgün, Karadeniz \& Demirel, 2012; Karasar, 2011).

\section{The study group}

The participants of the study included the 4 th- 8 th grades attending three schools which have SBs used in their classes, with both primary and secondary stages, located in Malatya province, Turkey. These three schools are qualified as higher, middle and lower socioeconomic status (SES) respectively as shown in Table 1. A total of 569 students were
.826 and .682 . The scale explains $60.457 \%$ of the total variance. Cronbach's Alpha on reliability of the scale is $a=.816$ for the first factor and $a=.821$ for the second factor. In this study, internal consistency coefficient of the scale in general was calculated as $\alpha=.836$ because if students' attitude differs or not in terms of several variables was determined according to total scores. This value shows this scale is reliable for this study as well.

\section{Data collection and analysis}

Before the data collection, students were informed about the aim of the study. Then, Smart Board Attitude Scale- 
SBAS was applied to the students chosen from volunteers from each grade.

Data obtained from the study was analyzed through statistical package program on computer. On students' attitudes towards smart board usage, for the options in the scale, for the positive ones from 5 to 1, for the negative ones from 1 to 5 reversely were given. Each student's total score was calculated this way. Total scores changed between 10 and 50 .

Frequency and percentage values of students' answers given to the items were calculated and shown in the table. Moreover, arithmetical mean of total scores obtained from the scale was calculated. How the attitudes of the students towards smart board usage is in general was tried to be determined in this way. For the analysis used to determine if there is significant difference between students' attitudes about smart board usage in terms of their gender, number of students in class, school type and grade, non-parametric statistics (Kruskal Wallis-H and Mann Whitney U) was used because there is no normality for the scores (Büyüköztürk, 2012). Significance degree $(p)$ was set to .05 .

\section{Findings}

Under this heading, findings of the study are given respectively according to sub-problems.

\section{Findings related to first sub-problem}

The findings about how the attitudes of the students towards smart board usage in general is are given in table 2 .
As can be seen in Table 2, elementary education students' answers to the positive items $(2,3,5,6$ and 10$)$ of the scale were mostly "strongly agree" and "agree". On the other hand, their answers to the negative items $(1,4,7,8$ and 9) were "strongly disagree" or "disagree". It can be said that elementary education students' attitudes towards the use of smart board is positive in general. Furthermore, as can be seen in table 2 the fact that the arithmetical mean of students' total attitude scores is 40.65 considering the highest score is 50 , supports this comment.

\section{Findings related to second sub-problem}

Findings about if there is a significant difference between students' attitude towards the use of smart board in terms of their gender, the number of students in the class, school type and grade are given in table 3, 4, 5 and 6.

As can be seen at table 3 , no significant difference $(U=$ 39399.50, $p>$.05) was found between students' attitude scores towards smart board usage in terms of gender. This finding can be interpreted as students' attitudes towards smart board usage is similar.

As can be seen at table 4 , there was a significant difference $(U=23485 ; p<.05)$ between students' attitude scores towards smart board usage in terms of the number of students in the class. The mean rank of attitude scores of the students in the classes that has 16-25 students is more than the ones which has 26-35 students. This finding can be interpreted as the classes having less students may cause positive attitude about smart board usage. In other words, less crowded classes may cause positive attitudes because it raises interaction with the smart board.

As can be seen at table 5 there was a significant difference $(X 2=38.24 ; p<.05)$ between students' attitude scores about

Table 2. The distribution of students' attitudes towards smart board usage and statistics on total scores from the scale

\begin{tabular}{|c|c|c|c|c|c|c|c|c|c|c|c|c|}
\hline \multirow[b]{2}{*}{ Items } & \multicolumn{2}{|c|}{$\begin{array}{l}\text { Strongly } \\
\text { Agree }\end{array}$} & \multicolumn{2}{|c|}{ Agree } & \multicolumn{2}{|c|}{$\begin{array}{l}\text { Slightly } \\
\text { Agree }\end{array}$} & \multicolumn{2}{|c|}{ Disagree } & \multicolumn{2}{|c|}{$\begin{array}{l}\text { Strongly } \\
\text { Disagree }\end{array}$} & \multicolumn{2}{|c|}{ Total } \\
\hline & $f$ & $\%$ & $f$ & $\%$ & $f$ & $\%$ & $f$ & $\%$ & $f$ & $\%$ & $f$ & $\%$ \\
\hline $\begin{array}{l}\text { 1. I am fed up with teachers' } \\
\text { teaching with a Smart Board.* }\end{array}$ & 29 & 5.1 & 14 & 2.5 & 43 & 7.6 & 73 & 12.8 & 410 & 72.1 & 569 & 100 \\
\hline $\begin{array}{l}\text { 2. I can concentrate better when } \\
\text { lessons are taught with a Smart Board. }\end{array}$ & 319 & 56.1 & 139 & 24.4 & 68 & 12.0 & 21 & 3.7 & 22 & 3.9 & 569 & 100 \\
\hline 3. I study harder thanks to Smart Board. & 189 & 33.2 & 124 & 21.8 & 116 & 20.4 & 72 & 12.7 & 68 & 12.0 & 569 & 100 \\
\hline $\begin{array}{l}\text { 4. I cannot understand anything when a } \\
\text { Smart Board is used.* }\end{array}$ & 25 & 4.4 & 14 & 2.5 & 39 & 6.9 & 56 & 9.8 & 435 & 76.4 & 569 & 100 \\
\hline $\begin{array}{l}\text { 5. I enjoy lessons taught with a Smart } \\
\text { Board. }\end{array}$ & 364 & 64.0 & 109 & 19.2 & 52 & 9.1 & 23 & 4.0 & 21 & 3.7 & 569 & 100 \\
\hline $\begin{array}{l}\text { 6. As the Smart Board is used in lessons I } \\
\text { come to school more willingly. }\end{array}$ & 241 & 42.4 & 100 & 17.6 & 89 & 15.6 & 68 & 12.0 & 71 & 12.5 & 569 & 100 \\
\hline $\begin{array}{l}\text { 7. Using a Smart Board in lessons causes } \\
\text { waste of time.* }\end{array}$ & 62 & 10.9 & 41 & 7.2 & 84 & 14.8 & 96 & 16.9 & 286 & 50.3 & 569 & 100 \\
\hline $\begin{array}{l}\text { 8. Actually there is no need to use a } \\
\text { Smart Board in lessons.* }\end{array}$ & 37 & 6.5 & 21 & 3.7 & 45 & 7.9 & 101 & 17.8 & 365 & 64.1 & 569 & 100 \\
\hline $\begin{array}{l}\text { 9. I think Smart Board is not different } \\
\text { from normal board in terms of learning.* }\end{array}$ & 55 & 9.7 & 37 & 6.5 & 55 & 9.7 & 85 & 14.9 & 337 & 59.2 & 569 & 100 \\
\hline $\begin{array}{l}\text { 10. I raise my hand more offen } \\
\text { during lessons thanks to Smart Board. }\end{array}$ & 231 & 40.6 & 121 & 21.3 & 93 & 16.3 & 42 & 7.4 & 82 & 14.4 & 569 & 100 \\
\hline Score type & & Min. & & & Max. & & & $M$ & & & SD & \\
\hline Total score & & 10 & & & 50 & & & 40.65 & & & 7.92 & \\
\hline
\end{tabular}

* The item that includes negative attitude 
Table 3.The MWU results of students' attitude scores about smart board usage in terms of gender

\begin{tabular}{lccccc}
\hline Gender & $n$ & Mean rank & Sum of ranks & $U$ & $p$ \\
\hline Girl & 257 & 287.69 & 73937.50 & 39399.50 & .72 \\
\hline Boy & 312 & 282.78 & 88227.50 & & \\
\hline Total & 569 & & & & \\
\hline${ }^{*} p<.05$ & & & & &
\end{tabular}

Table 4. The MWU results of students' attitude scores about smart board usage in terms of the number of student in the class

\begin{tabular}{lccccc}
\hline $\begin{array}{l}\text { The number of student in the } \\
\text { class }\end{array}$ & $n$ & Mean rank & Sum of ranks & $U$ & $p$ \\
\hline $16-25$ & 168 & 345.71 & 58079 & 23485 & $.0 *^{*}$ \\
\hline $26-35$ & 401 & 259.57 & 104086 & & \\
\hline Total & 569 & & & & \\
\hline$*_{p}<.05$ & & & &
\end{tabular}

Table 5. The Kruskal Wallis-H results of students' attitude scores about smart board usage in terms of school type they study

\begin{tabular}{|c|c|c|c|c|c|c|}
\hline School type & $n$ & Mean rank & $d f$ & $X^{2}$ & $p$ & $\begin{array}{c}\text { Significant difference } \\
(\mathrm{MWU})\end{array}$ \\
\hline 1. Higher SES & 168 & 345.71 & 2 & 38.24 & $.00 *$ & $1>2$ \\
\hline 2. Middle SES & 219 & 277.22 & & & & $1>3$ \\
\hline 3. Lower SES & 182 & 238.32 & & & & $2>3$ \\
\hline
\end{tabular}

${ }^{*} p<.05$

Table 6. The Kruskal Wallis-H results of students' attitude scores about smart board usage in terms of their grades

\begin{tabular}{lcccccc}
\hline Grade & $n$ & $\begin{array}{c}\text { Mean } \\
\text { rank }\end{array}$ & df & $X^{2}$ & $p$ & $\begin{array}{c}\text { Significant difference } \\
(\text { MWU) }\end{array}$ \\
\hline $4^{\text {th }}$ & 62 & 286.92 & 4 & 11.92 & $.02^{*}$ & $7>8$ \\
\hline $5^{\text {th }}$ & 111 & 307.84 & & & & $5>8$ \\
\hline $6^{\text {th }}$ & 146 & 285.05 & & & & $6>8$ \\
\hline $7^{\text {th }}$ & 132 & 303.31 & & & \\
\hline $8^{\text {th }}$ & 118 & 241.96 & & & \\
\hline Total & 569 & & & & \\
\hline${ }^{*}<.05$ & & & & &
\end{tabular}

smart board usage in terms of the school type. According to the MWU analysis done to determine between which school types the difference is, the mean rank of total attitude scores of the students in school with the higher socio-economic status is higher than mean ranks of the students in other schools. Furthermore, the mean rank of total attitude scores of the students in the school with the middle socio-economic status is higher than the mean rank of the students in the school with lower socio-economic status. This finding can be interpreted as students' studying at a school in which socio-economic status is higher might cause positive attitude about smart board usage in lessons.

As can be seen at table 6 , there was a significant difference $\left(X^{2}=38.24 ; p<.05\right)$ between students' attitude scores in terms of students' grades. According to the MWU analysis done to determine between which grades the difference is in, the mean rank of attitude scores of the students in 5 th, $6^{\text {th }}$ and $7^{\text {th }}$ grade is higher than the ones' in $8^{\text {th }}$ grade. This finding can be interpreted as the students in lower grades have more positive attitude towards smart board usage than $8^{\text {th }}$ grade students.

\section{Conclusion and Discussion}

Providing students with knowledge and skills in education-training processes is possible by setting various factors to function systematically. One of these factors is teaching materials and equipment. Today the materials compatible with digital technology have replaced the simple-structured materials used in the past. One of these technologies, the smart boards (SBs), though called with different names, are becoming widespread day by day (Erduran \& Tataroğlu, 2009; Lan \& Hsiao, 2011). No matter at which educational stage SBs are used, they contribute to education-training processes. Some of the benefits of the SBs include teacher-student interaction, supporting creative thinking, effective use of visual presentation materials, providing motivation and considering individual differences.

Besides these contributions of SBs, they have limitations like failure to be used in every lesson and with every teaching method according to the conditions of use. These limitations and contributions can cause differ- 
ent views, interests and attitudes regarding SBs among teachers and students. In this study, elementary education students' $\left(4^{\text {th }}-8^{\text {th }}\right.$ grades) attitudes towards the use of SBs in classroom are investigated.

In this research, it was concluded that elementary education students generally have positive attitudes towards the use of SBs. In the relevant literature, although some are at the secondary education stage, there are also some studies which reached the same conclusion (Akgün \& Koru Yücekaya, 2015; Çalışkan \& Altundaş, 2016; Demircioğlu \& Demircioğlu, 2015; Özgen \& Tum, 2018; Smith, Higgins, Wall \& Miller, 2005) Additionally, Sünkür, Arabacı and Şanlı (2011) reached the conclusion that students enjoyed using SBs and so, suggesting that students have positive attitudes. On the contrary, in a study related to the use of SBs in Math lesson (Gündüz \& Çelik, 2015) it was seen that students have negative attitude. According to this conclusion, students' attitudes towards SBs can be at different levels due to varying factors but in general studies show that it is important that students have positive attitude. That can be evaluated as a reflection of the functions provided by the SBs to students during the lessons. Additionally, students' interests and positive attitudes towards SBs will contribute to use these materials more effectively. Another conclusion drawn from this research is that primary education students' attitudes towards the use of SBs do not differ according to gender. In the literature, it is seen that there are studies which found similar results (Bağcl, 2013; Çalışkan \& Altundaş, 2016; Demircioğlu \& Demircioğlu, 2015; Günbatar \& Gökçearslan, 2017; Gündüz \& Çelik, 2015; Kırbağ Zengin, Kırılmazkaya \& Keçeci, 2011; Korucu, Usta \& Toraman, 2016;). Günbatar and Gökçearslan (2017) concluded that there is a difference in students' negative attitudes towards SBs according to gender, while there is no difference between total attitude scores got from the scale. On the other hand, in two studies (Kaya \& Aydın, 2011; Özgen \& Tum, 2018) it was found that there is a difference in attitudes towards SBs according to gender. In this research and in most of the other researches reviewed, no significant difference was found in terms of gender, which suggests that gender is not an effective variable in students' attitudes towards SBs. However, presence or lack of difference in students' attitudes towards SBs according to gender is up to their interaction conditions with this instructional technology.

According to the analysis on the number of students in the class, it is found that there is a significant difference between students' attitudes towards the use of SBs. In the classes with fewer students (16-25 people), students have higher positive attitude scores. Having fewer students in a class is important in terms of enhancing the time of interaction with SBs. This can cause positive attitudes. Although this conclusion obtained from the research suggests that the number of students in the class is an important factor about attitudes towards SBs, no researches have been encountered in the literature which investigates SBs' effects on students' attitudes according to the number of students in the class.

According to the school type, there is a significant difference between students' attitudes towards the use of SBs. Because students' attitude scores towards SBs enhanced, as the socio-economic status of schools increased. The socio-economic status of primary and secondary schools which students attend cause difference in students' attitudes towards SBs in this study. Although this conclusion obtained from the research show that school type is an important factor about attitudes towards SBs, no researches have been encountered in the literature which investigates SBs' effects on students' attitudes according to school types.

A significant difference was found between students' attitudes towards the use of SBs according to grades $\left(4^{\text {th }}\right.$ $\left.8^{\text {th }}\right)$. In addition to studies which have similar conclusions (Çalışkan \& Altundaş, 2016; Demircioğlu \& Demircioğlu, 2015; Günbatar \& Gökçearslan, 2017; Korucu, Usta \& Toraman, 2016; Özgen \& Tum, 2018), there is also a study which found no difference in students' attitudes towards SBs. In one of the studies (Çalışkan \& Altundaş, 2016) in which there is a difference in attitudes towards SBs according to grades, while attitude score means/ positive attitudes decreased towards the lower classes; in others, they decreased towards the upper classes. These conclusions are important in terms of attitudes towards SBs. Because the presence or lack of difference between students' attitudes towards SBs according to grades and positive attitudes' decreasing towards lower or upper classes prompts the researchers to investigate how SBs are used.

Furthermore, there are some studies that show using smart board in lessons affect not only attitude but also affective, cognitive (interest, success, enjoying learning etc.) qualities in a positive way (Davidovitch \& Yavich, 2017; Digregorio \& Sobel-Lojeski, 2010; Francis, 2017; Luo \& Yang, 2016; Nejem \& Muhanna, 2014; Torff \& Tirotta, 2010). Those studies revealed that technological materials including smart boards would be useful when they are actively used in education.

According to the conclusions obtained from the research, if it is considered that SBs are becoming widespread in learning-teaching processes day by day, it is suggested that both quantitative and qualitative researches are conducted to investigate how SBs are used. As the number of students is an effective factor on students' attitudes towards SBs, classrooms can be organized so as to include 20-24 people. Additionally, investigate how such affective variables such as interest; motivation etc. affect learners' attitudes towards SBs can also. These suggestions were generally done based on the findings of the research. However, usage of smart boards can change according to education systems. Therefore, the place of the smart boards in educational processes can be handled more comprehensively through researches both in Turkey and abroad.

\section{References}

Adıgüzel, T., Gürbulak, N. \& Sarıçayır, H. (2011). Akıllı tahtalar ve öğretim uygulamaları. Mustafa Kemal Üniversitesi Sosyal Bilimler Enstitüsü Dergisi, 15(8), 457-471.

Akgün, M. \& Koru Yücekaya, G. (2015). Akıllı tahta kullanımına yönelik öğrenci tutumu ve öğretmen görüşlerinin incelenmesi (Ankara ili örneği) NWSA-Qualitative Studies, E0023, 10(3), 1-11.

Ateş, M. (2010). Ortaöğretim coğrafya derslerinde akıllı tahta kullanımı. Marmara Coğrafya Dergisi, 22, 409-427.

Bağcl, H. (2013). Fatih projesi çerçevesinde ortaöğretim öğrencilerinin etkileşimli tahtaya yönelik görüşlerinin incelenmesi. [In favour of fatih project: review of students' opinions related to the smart boards]. Unpublished master's thesis, Okan Üniversitesi, İstanbul, Turkey. 
Beeland, W. D. (2002). Student engagement, visual learning and technology: Can interactive whiteboards help? Retrieved from http:// citeseerx.ist.psu.edu/viewdoc/download?doi=10.1.1.135.3542\&rep=rep1\&type=pdf

Büyüköztürk, Ş. (2012). Sosyal bilimler için veri analizi el kitabı (16. baskı). Ankara: Pegem A Yayıncılık.

Büyüköztürk, Ş., Çakmak, E. K., Akgün, Ö. E., Karadeniz, Ş. \& Demirel, F. (2012). Bilimsel araştırma yöntemleri (11. baskı). Ankara: Pegem A Yayıncılık.

Çalışkan, H. \& Altundaş, B. (2016). Öğrencilerin Sosyal Bilgiler derslerinde akılı tahta kullanımına yönelik tutumlarının incelenmesi. V.International Symposium On Social Studies Education, 28-30 Nisan 2016, Pamukkale University, Denizli,Turkey.

Çelik, S. \& Atak, H. (2012). Etkileşimli tahta tutum ölçeğinin geçerlik ve güvenirlik çalışması. Anadolu Journal of Educational Sciences International, 2(2), 43-60.

Davidovitch, N. \& Yavich, R. (2017). The effect of smart boards on the cognition and motivation of students. Higher Education Studies, 7(1), 60-68.

Demircioğlu, G. \& Demircioğlu, H. (2015). Öğrencilerin kimya derslerinde akıllı tahta kullanımına yönelik tutumlarının farklı değişkenler açısından incelenmesi. Journal of Research in Education and Teaching. 4(2), 387-395.

Digregorio, P. \& Sobel-Lojeski, K. (2010). The effect of IWBs on students' performance and learning: A literature review. Journal of Educational Technology Systems, 38(3), 255-312.

Elaziz, F. M. (2008). Attitudes of students and teachers towards the use of interactive whiteboards in EFL classrooms. Unpublished master's thesis, Bilkent University, Ankara, Turkey.

Erduran A. \& Tataroğlu, B. (2009). Eğitimde akıllı tahta kullanımına ilişkin fen ve matematik öğretmenlerinin görüşlerinin karşılaştırılması. 9th International Educational Technology Conference (IETC2009), 6-8 Mayıs 2009, Ankara, Turkey.

Francis, J. (2017). The effects of technology on student motivation and engagement in classroom-based learning. Unpublished doctoral thesis. Faculty of the College of Graduate and Professional Studies, University of New England, USA. Retriewed from: http://dune.une.edu/cgi/viewcontent.cgi?article $=1120 \&$ context $=$ theses

Geer, R. \& Barnes, A. (2007). Cognitive concomitants of interactive board use and their relevance to developing effective research methodologies. International Education Journal. 8(2), 92-102.

Günbatar, M. S. \& Gökçeaslan, Ş. (2017). Ortaokul Öğrencilerinin Etkileşimli Tahtaya Yönelik Tutum ve Öğrenme Algıları Üzerine Bir İnceleme. Mersin Üniversitesi Ĕgitim Fakültesi Dergisi, 13(2): 497-511.

Gündoğdu, T. (2014). Bir öğretme-öğrenme aracı olarak akıllı tahta. Akademik Sosyal Araştırmalar Dergisi, 2 (6), 392401.

Gündüz, S. \& Çelik, H. C. (2015). Öğrencilerin matematik dersinde akıllı tahta kullanımına yönelik tutumlarının çeşitli değişkenler açısından incelenmesi.
Dicle Üniversitesi Ziya Gökalp Eğitim Fakültesi Dergisi, 25, 157-174.

Hall, I. \& Higgins, S. (2005). Primary school students' perceptions of interactive whiteboards. Journal of Computer Assisted Learning, 21, 102-117.

Higgins, S., Beauchamp, G. \& Miller, D. (2007). Reviewing the literature on interactive whiteboards, Learning, Media and Technology, 32(3), 213-225.

Kağıtçıbaşı, Ç. (2008). Günümüzde insan ve insanlar (11. basım). İstanbul: Evrim Yayınları

Karasar, N. (2011). Bilimsel araştırma yöntemi (22. basım). Ankara: Nobel Yayın Dağıtım.

Kaya, H. \& Aydın, F. (2011).Sosyal Bilgiler dersindeki coğrafya konularının öğretiminde akıllı tahta uygulamalarına ilişkin öğrenci görüşleri. Journal of World of Turks, 3(1), 179-189.

Kenar, i. (2012). Teknoloji ve derslerde teknoloji kullanımına yönelik veli tutum ölçeği geliştirilmesi ve tablet PC uygulaması [Development of parents' attitude scale regarding technology and use of technology in classes and tablet PC application]. Eğitim Bilimleri Araştırmaları Dergisi - Journal of Educational Sciences Research, 2 (2), 123-139.

Kennewell, S. \& Beauchamp, G. (2007). The features of interactive whiteboards and their influence on learning. Learning, Media and Technology. 32(3), 227-241

Kırbağ Zengin, F., Kırılmazkaya, G. \& Keçeci, G. (2011). "Akıllı tahta kullanımının ilköğretim öğrencilerinin fen ve teknoloji dersindeki başarı ve tutuma etkisi", 5th International Computer \& Instructional Technologies Symposium, 22-24 Eylül 2011, Fırat Üniversitesi, Elazı̆̆.Turkey.

Korucu, A. T., Usta, E. \& Toraman, L. (2016). Ortaokul öğrencilerinin etkileşimli tahta kullanımına yönelik tutumlarının farklı değişkenler açısından incelenmesi. Bartın Üniversitesi Eğitim Fakültesi Dergisi, 5(3), 690-717.

Lan, Tian-Syung, \& Hsiao, Tsung-Yen (2011). A study of elementary school students' viewpoints on interactive whiteboard. American Journal of Applied Sciences, 8(2), 172-176.

Luo, Yi-Fang \& Yang, S. C. (2016). The effect of the interactive functions of whiteboards on elementary students' learning. The Journal of Educational Computing Research, 54(5), 680-700.

Nejem, K.M. \& Muhanna, W. (2014). The effect of using smart Board on mathematics achievement and retention of seventh grade students. International Journal of Education, 6(4), 107-118.

Özgen, K. \& Tum, A. (2018). Ortaokul öğrencilerinin matematik derslerinde akıllı tahta kullanmaya yönelik tutumlarının bazı değişkenlere göre incelenmesi. Cumhuriyet International Journal of Education, 7(1), 16-39.

Şad, S.N. (2012). An attitude scale for smart board use in education: validity and reliability studies. Computers \& Education, 58(3), 900-907.

Smith, H. J., Higgins, S., Wall, K., \& Miller, J. (2005). Interac- 
tive whiteboards: Boon or bandwagon? A critical review of the literature. Journal of Computer Assisted Learning, 21, 91-101.

Sünkür, M., Arabacı, İ.B. \& Şanlı, Ö. (2012). Akıllı tahta uygulamaları konusunda ilköğretim II. kademe öğrencilerinin görüşleri (Malatya ili örneği). E-Journal of New World Sciences Academy NWSA-Education Sciences. 7, 1, 3130321.

Torff, B. \& Tirotta, R. (2010). Interactive whiteboards produce small gains in elementary students' self-reported motivation in mathematics. Computers\& Education, 54(2), 379-383.

Türel, Y. K. \& Demirli, C. (2010). Instructional interactive whiteboard materials: Designers' perspectives. Procedia Social and Behavioral Sciences, 9, 14371442. 
This page is intentionally left blank www.iejee.com 